\title{
The Future of North-South Dialogue in the Context of Globalization
}

\author{
Dr. Mohammad Hamad Al-Katatsheh \\ Associated Prof of Politics \\ University of Mutta-DEPT of politics, Mot'a- Po.Box 7 Karak- Jordan \\ E-mail: alkatatsheh@hotmail.com
}

Dr. Mohammad Salim Al-Rawashdeh

Assistant Prof of International Relations, Albalqa Applied University - Amman Collage

E-mail: jordan1uni69@yahoo.com / jordan1uni69@ hotmail.com

Received: December 25, 2010

Accepted: February 16, 2011

doi:10.5539/jpl.v4n2p108

\begin{abstract}
One of the most important characteristic features of today’s digital age is the current and spread globalization, which has multi- political, cultural, social and economic aspects. The concept of globalization is a dialectic phenomenon that is seen by many writers as a necessary evil. In the present paper researchers explain the idea that globalization plays a real role in reducing the gap between the North and South, particularly issues related to economic gaps in order to achieve justice and the interests of the people of these States.

The current paper attempts to clarify the current international factors stimulating this dialog and the suitability of the global climate participating in enhancing the efforts behind the dialogue. The paper focuses on issues related to dialogue in the context of globalization, the extent of the role of globalization in reducing the gap between the North and South, and the dominant role of the United States in this process.

The current paper concludes that the globalization with all of its instruments reflects the U.S. hegemony over the whole process of dialogue between the states of North and South.
\end{abstract}

Keywords: Politics, International relations, International and political economy

\section{Introduction:}

The term globalization is one of the most important and latest terms in common use, with expanded circulation very quickly during the past few years. Perhaps the reason for this is the linking of this term with deep and fast changes experienced by the world at the present time, in all political, economic, social or cultural and technological terms. This means that the local, regional and international variables interfere with each other, where it becomes obscure what is local what is regional or global, but global and cosmic effects become inclusive of all countries and peoples. Whatever may be said, the essence of the process of globalization represented in the ease of movement of people, information and goods between the countries on a global scale, and the effect of this on economic relations in general and the North and South dialogue in particular.

The economic gap between North and South gave birth to the idea of dialogue; the results may lead to reduce that gap, in order to re-examine the structure of the global economic system, so the system is established according to more just foundations and objectives, in the hope this would ease the suffering of developing countries during the past years. The dialogue between developing countries and industrialized countries is only to compromise on contentious economic issues, and to reassure the peoples of both parties of the coming economic risks, and to defeat them by the countries of the North's claim of the South states.

The international political economy is a study field, an area of issues, problems and methods of thinking in both politics and the world economy. It is appropriate, particularly in the context of this research, that we are now in the international political economy arena and the future of North-South dialogue in a globalized world, because the international political economy is widely regarded as on a large scale the focus of basic forces of globalization and the main method in which globalization is moving in all parts of the world.

In other words, what is happening in international economic relations and dialogues will be a result of factors and influences, and various forces, and will include the importance of what is produced, how, and the nature of technology and its range and the developments in speed, reliability and cost of transport and communications. Finally, it is ultimately a reflection of changes caused by globalization. These changes are wide-ranging but include 
changes in the nature of production, trade and their expansion, and the growth of very big companies over the world, and finance internationalization, and the interdependence of people and businesses through international networks.

Since dialogue between north and south is going on in the orbit of international political economy, what happens in the international economy is the possibility of globalization strengthening and deepening. Therefore, it has a real and possible impact on the nature of the North-South dialogue.

Hence, if we live already in a globalized world now, the nature of relationships and common trends in North-South dialogue will show that because these relations are changing, first as a response to new forms of production, investment, finance and trade, which stems from important elements of the state of globalization, and that any changes in these relationships will have a very significant impact on national governments and international relations, and therefore the results of the dialogue of the North and South.

\section{Objectives of the study:}

The study aims to overview the dialogues that took place between North and South (industrialized and developing) countries, and the future of the dialogue in the context of globalization, by focusing light on the impact of globalization through the globalization institutions and the role of the United States of America. From this point of view, the study includes the following:

1. Definition of globalization and economic globalization.

2. Definition of dialogue and conferences that took place between North and South.

3. Statement trends North-South dialogue.

4. Definition of the global economic system.

\section{Importance of the study:}

The importance of the study emanates from its being one of few studies which provide an analysis of North - South dialogue after World War II and the efforts of the victor states in establishing an international economic system, hoping to instill the principles of justice between North and South and to organize economic transactions on an international level, but the results of that dialogue proved below par. Furthermore, the role of globalization in the developments and data and the future of that dialogue in delineated.

\section{Problem of the study:}

The North-South dialogue has seen many fluctuations: the relationship that began in the seventies between North and South was reinforced by a belief on both sides that what can be achieved through reforms will lead to benefit, stability and prosperity of the international community. There have been convictions and moral grounds by many officials in the North states that confirm this trend, but outstanding issues remain, including technology, oil and finance, trade and other issues that form pictures of the dialogue between the two parties, especially globalization with its various institutions that are drawing these images and decide the fate of the dialogue. Therefore, the study answers the following questions:

1. How is the future of the dialogue shaped in the context of globalization?.

2. Does globalization lead to growing the gap between north and south, or help to resolve the differences between them?

3. What is the role of the United States as it controls the tools of globalization in such a dialogue through aid provision?

\section{Hypothesis of the study:}

The study is based on the following premise key:

There is a relationship between globalization and the nature of dialogue between North and South.

Next, several subsidiary hypotheses branch from this hypothesis:

1. That globalization leads to a growing gap between North and South.

2. Dialogue between North and South in the context of globalization tends towards complexity and crisis.

\section{Methodology of the study:}

This study depended on the Analytical Approach, whereby it focuses on the analysis of conferences that took place between North and South, in addition to these conferences organized by the United Nations to resolve the issues that led to the name: North-South dialogue. On another side, this approach focuses on analyzing that dialogue in the 
context of globalization, and analysis of the features of the future dialogue by measuring the extent of the role and importance of globalization to decide that future.

\section{Previous studies:}

In fact, we tried hard to find studies include the same subject but we are unable to find, this does not mean the absence of studies on the subject in one form or another. Studies that we've talked to are that studies which cover an aspect of the topics North-South dialogue, including globalization and its impact on poverty, as poverty is one of the topics posed and still posed by developing countries on the dialogue table, in addition, some other studies talk about the role and impact of the institutions of globalization as the World Trade Organization on developing countries.

Mahmoud Study (2006), entitled "The impact of globalization on poverty in developing countries with reference to Egypt."

This study aimed to test whether globalization leads to poverty reduction so as to achieve one of the most important Millennium Development Goals adopted by 189 countries in 2000.

The study showed how difficult the existence of a specific and clear definition of poverty or globalization. The study used data collected for 17 developing countries in similar economic and social conditions to a large possible amount to determine a set of consistent data, the result of evaluation is the lack of the impact of globalization on the poverty rate in the study sample.

The study concluded that it must to be careful of increasing international integration, which carry more instability degree of, especially in light of economic, political or social conditions.

\section{Mamsr study (2002), entitled "The impact of globalization on the contemporary Arab.}

This study aimed to describe the effect of globalization on social aspect in developing countries and the effects of behind it.

The study concluded that economic reform programs represented in the International Monetary Fund and the World Bank led to widening the social gap in developing countries, between different classes, and to double the number of unemployed people as they hit their proportion in some Arab countries to $30 \%$ of total workforce.

\section{Al Tai Study (2004), entitled "World Trade Organization and its economic effects in developing countries.}

This study aimed to show the extent of the impact of globalization institutions, including the World Trade Organization (WTO) as successor to the General Agreement on Tariffs and Trade (GATT) on developing countries economy, so I felt developing countries at the end of GATT negotiations it was still on the sidelines of that process, the World Trade Organization have tried Since its inception in 1995 to increase the speed of globalization and the degree of economic openness to the Arab economies and developing countries in the global economy.

The study comes out with a set of results the most important may be is that oil countries are non benefit from the results of this agreement, it still imports oil to the industrialized countries, subject to certain customs duties, which has affected export prices of this material.

\section{What our study covers:}

\section{1 definition of globalization and economic globalization}

The use of term globalization was common in the recent period of time to the point of downloading the contents include the globe, and multiple economic, social, political and cultural dimensions. the emergence of globalization is currently accompanied with technical sophistication that humanitarian enormous know, but there is no agreed for comprehensive definition for globalization. The consensus on the definition of this phenomenon are many and sometimes contradictory. Anthony Giddens see that it must be understood as a process of globalization the reorganization of time and distance in social relations. (Haddad, 2000: p. 518). Globalization as definition "refers to all processes which comprises the world's population under a single global community called the global community." As well known as the "intersection in the global collected together the communities that had previously been on our planet, that are isolated and turned to the communities that all are interdependent and the unity of one world." (Bayliss and Smith, 2004: p. 29).

The definition of economic globalization, verified by Dr. Mohammed Suquir, "is integration of production, distribution and use of goods between the economies of the world and represent the manifestations of globalization on the level of production factors in increasing the flow of capital and labor through borders at the level of the product in the growth of world trade and foreign direct investment and capital markets, and cancellation the flow of capital and trade on two levels domestically and internationally. "(Azzam, 2003: pp 23-42). Economic globalization is focused functionally on the state as an interrelated economic phenomena series, such phenomena including the 
liberation of markets, privatization of assets, and the withdrawal of the State from performing some functions and spreading of technology and distribution cross-continents for factory's production through foreign direct investment, and integration between capital markets. An economic globalization as a definition refers to "the widespread term phenomenon all over the world for sales, production, and manufacturing processes, which is a reformulation of the partition between the International Action." (Massad, 2004: pp 26-27). Talking about economic globalization makes us to talk about the huge superiority of capitalist, led by the United States of America, economic system, social capitalist dominance and spread of a new dynamic based on regaining market economy and its spread in new dynamic method based on the market economy, and the third wave (information revolution), and the integration of the most national economies and market global capitalism, to make these economies as hostages to the concepts of market and monopoly competition controlled by giant Economic Summits, passing the limitations and restrictions based on market forces and under the supervision of the institutions of three economic globalization, the International Monetary Fund, International Bank for Reconstruction and Development, the World Trade Organization, which is the successor to GATT agreements. There are those who think that globalization is essentially an economic concept before it would scientifically, politically, culturally, or socially term. As Dr. Abdalkhalq Abdullah said that from more things which comes to mind when talking about globalization is economic globalization, and this deep and organic link between globalization on one hand, globalization economic on the other hand return to the phenomena of economic globalization manifestations which is the most visible in this stage of the appear and development of globalization as a new historical moment. (Abdullah, 1999: p. 25). This is confirmed by Dr Saeed Hareb, when he said that economic axis seems to be more fast axis themes towards globalization, GATT international is an example of this globalization. The volume of international trade increased during the past 25 years by $255 \%$, as trade, service liberalized, capital money is moving between most of the States freely and without barriers, and the role of multinational corporations and institutions expanded, passing the borders (Harib, 2000: p. 12). So, what is the meaning of all of these consensus, the economic globalization suggesting that the world which was formed in the nineties has become a world without economic borders, different economic systems are converging and overlapping and moving in each other, there is no longer limits and borders between them, and that the global economic system today is a single system governed by global common foundations , and is run by companies and organizations with a global impact on all local economies. As for the trade and financial markets the world, as Malcolm Waters says, it was not unity more than any other time, but are beyond the control of all the countries of the world, including the largest and the richest. (Abdullah, 1999: p. 26). This was confirmed by Dr. Mohammed Ahmed Azzam, in his book (Globalization) when he said: economic globalization means a shift towards a market economy and preventing the State from interfering in economic activities, and raising the barriers and borders in front the movement of money and transferring capitalist system from the concepts and mechanisms, multinational companies is one of the most important globalization institutions, as well as international financial institutions like the World Bank and International Monetary Fund. (Azzam, 2003: pp 24-25).

\section{2. the beginning of North-South dialogue}

In this chapter we show a historical panorama of the dialogue between the north and south and the directions of north and south.

\subsection{1 chronology of the conferences of the dialogue between North and South}

First: can be dated in the limits of 1961, when the first UN conference on Development and Trade where that was the first time that highlights the coalition of developing countries in voting in the United Nations for convening the conference, overcoming the opposition of the rich countries for the conference. Then the United Nations Conference 1964. (D. Hadiyyeh, 1986, p.: 21).

\section{Second: dialogue stop in 1973 after petroleum crisis, and the position of the Petroleum Exporting Countries}

Beside Arabs in the October 1973 war and their decision to reduce production and prevention from the States supporting Israel . which forced the capitalist countries that engaged in a dialogue with developing countries in order to modify the existing international economic system, where developing countries was seeing that the problem lies in this existing system with all of its unfairness and injustice to them, while the capitalist countries see that the cause of the economic crisis is reducing of the amount of oil production and raising its prices and the responsibility for that is Petroleum Exporting Countries, then dialogue resumed in 1974 when France sought to host a preparatory conference includes ten countries to discuss procedural problems, However, the United States and some countries, including Algeria, had received for various reasons, the French proposal with large reservations, and in November 1974, U.S. Secretary of State said that the United States interested particularly in the solidarity of the Western world in the face of farm OPEC and the immediate goals of the United States are: energy conservation, and search for alternative sources with attractive prices. (Almkhadmi, 2004, p.: 41). 


\section{Third: The sixth special session of the General Assembly of the United Nations}

The sixth special session held in April and May 1974 and their discussions resulted to adopt two documents on highest degree of importance, the first: Declaration on the establishment of new international economic system (Resolution No. 3201) and the second: Action Programme for a New International Economic system (resolution 3202), so that this system can based on justice, sovereign equality, interdependence, mutual interest and cooperation between States, regardless of their economic and social development. (Dr. Hadiyyeh, 1986, p.: 22).

\section{Fourth: the seventh special session of the General Assembly.}

Held in September 1975, after (Lima) meeting for developing countries in August 1975, this session focused on issues related with trade and reforming international monetary system, manufacturing, food and agriculture and cooperation among developing countries ... some industrialized countries seized about some points in the final document, but the most points in the document approved by mutual consent of the year. (Dr. Hadiyyeh, 1986, p.: 23).

\section{Fifth: The Fourth United Nations Conference on Trade and Development (UNCTAD)}

Ministers of the (77) met in Manila in February 1976 in order to prepare and coordinate their positions for the fourth session of the United Nations Conference on Trade and Development held in Nairobi, May 1976, where Ministers declared in their statement that "they are convinced that it is necessary and urgent to make radical changes in economic relations in order to establish new relations based on justice and equity, that would remove the unfair economic structures imposed on developing countries. " The Ministers emphasized many points that will constitute a continuing reference for north and south experts, are as follows:

1_ Re-formation the structure of Commerce International which deals with the basic orientation, in order to keep on improving the purchasing power of the unitary income exports happened from developing countries.

2_ Re-consider the structure of global industrial production and global trade, to improve the contribution of developing countries in world exports of goods.

3_ Increasing the overall capacity of exports of developing country.

4_ Getting sensory privileges for developing countries in trade negotiations.

5_ Working on reforming the international monetary system, in order to respond with the interests and needs of developing countries.

6_ Access to short-and long-term finance funds for developing countries.

7_ Immediate action by developed countries and international organizations, would reduce the huge debt of the developing countries.

8_ Developing of national progress by technology acquisition responding to the needs of developing countries and their features and priorities of their projects, for technology adoption and dissemination.

9_ Make sure that the activities of multinational companies in developing countries, consistent with the objectives of national development, for free practice to the right of regulating the conduct of its work.

$10 \_$Work to intensify trade between developing and developed countries.

11_ Implementing effective measures, without delay, for the benefit of developing countries.

12_ strengthen the United Nations Conference on Trade and Development (CNUCED) in negotiations, so that this organization will be an effective tool in the United Nations negotiations in the field of development and trade. (Almkhadmi, 2004, p.: 56_57).

Sixth: the Paris Conference. After the oil prices amendment, and the fear of the occurrence of a global crisis, the most important features is inflation and recession and collapsing of the international system, France carried out the invitation of the Sixth United Nations special session. Michel Joubert suggested at that time a global conference energy under the supervision of the United Nations. After a month of this French initiative, the United States formed Agency International Energy (AIE) to be an important part in the Conference in order to respond to the Convention of the Petroleum Exporting Countries, but France refused at the time to participate in this process, so as to break this impasse, and 10 countries agreed to meet to discuss the issue of energy. Four countries of OPEC (Saudi Arabia, Algeria, Iran, Venezuela) and three industrialized countries (United States, and European Common Market, Japan) and three developing and petroleum-importing countries (Brazil, India, and Zaire) (Hadiyyeh, 1986, p. 25).

The French President Giscard d'Estaing announced at the time that France is seeking at the end of the first quarter of 1975 to collect the ten countries to discuss the issue of energy, already a few months later, the idea well received 
and in response to the majority, but two capitals showed their most caution and feared that. (Dr. qurm, 1977, p. 69). And the United States of America is interested in the solidarity of the Western world in the face of the Convention of Petroleum Exporting Countries, and it is aimed at energy conservation and search for alternative sources and at attractive prices, through the distribution of energy sources in times of crisis, and return to the collateral cash network to help industrialized countries most affected by the energy crisis. the Heads of OPEC to accept dialogue in principle, in Algeria, provided not only limited dialogue on the subject of oil, but should discuss the issue of raw materials and the issue of development and must therefore establish three committees: the Energy and raw materials and development Committee, and add then to another committee, the Cash Committee, and in February 11, 1976 the four committees started its work in Paris. the work of the committees done on two phases, the first half of 1976 and dedicated to the exchange of views on each of the topics on the agenda, and the second phase began in June 1976, the committees addressed a lot of the issues concerning the raw materials, energy and development, including a study of the evolution and conditions of raw materials presentation towards the needs of developing countries, oil prices and their relationship to energy supply and demand in the long run, technology transfer to developing countries and the development of infrastructure and other ... . (D. Ahmed, 1978, p.: 34).

VII: United Nations Conference for the Law of the Sea. The sea water problem were not on excluded on the North-South dialogue table, on the contrary the problem of the sea and the high seas were not inferior to other topics which are the subject of North-South dialogue. So from agreed from the nineteenth century, that the territorial waters is an integral part of the territory of the State subject to its laws and sovereignty, this area was estimated at six marine miles usually, but beyond that it is called high seas. However, the tremendous advances in technology and its monopoly by major capitalist countries, carry multiple effects in the areas of fishing and pollution of sea water and the bottom of oceans and seas, which contain huge quantities of mineral wealth resources in a time when depletion of the earth's surface, and this is what will touch damage in developing countries through pollution of its coasts and the lack of fish obtained, and non-participation in high seas resources, so it belongs to mankind. (dr Hadeyyeh, 1986, p.: 29). As a result of all this a law of the sea and the abandonment of the principle of freedom of the high seas should be drafted, and in this context the United Nations called for an international conference to develop a law of seas.

\section{3. trends in North-South dialogue.}

From recognition of the absence of heterogeneity and the difficulty exceeded of national interests, to rise, under the circumstance, to the level of interests of the north or the south as a whole, and also absence of common positions, for the north on the most important topics, like what happened in the seventh special session of the Organization of the United Nations, and dialogues tracking showed that North could not meet the urgent demands of developing countries side. so that Paris Conference under the influence of U.S. policy does not solve anything in this area because the opinions of participants in this conference was completely contradictory. (Kariminyuk, 1985, p.: 93). Paris Conference demonstrated clearly that the North was opposed to or estranged from each structural change in favor of the South would lead in its time to re-shuffle in favor of the South. Imagine the south world, which is interested from the global system to achieve international justice and to remove, or at least mitigate the impact of ignorance, disease and poverty and help in the liberation of political, economic, social and cultural development South's, the perception of the North, which concern actively from this global system to remove upon his states the risk of convulsions resulting from the cold war and the threat of nuclear weapons, and achieves international stability, and the prevention of terrorism and eliminate violence, and secure the freedom of international trade. (d. Masri, 1992, pp: 71). And because the Nordic countries need to provide labor and create new markets to promote their goods, this mechanism reflects the logic of the Northwest system the on the considerations to encourage consumption in the South world means to increase production in the north. (Al-Jihad Publications, 1988, p: 40). Therefore, we can say that Paris did not record any decisive progress in connection with main problems so that the new international economic order has remained as it was on the eve of the invitation to the Conference, briefly, there has been no radical change can affect the nature of the relations between developing and developed countries, in general it seems to be blame for this failure to the absence of political part on the side of industrialized countries, indicates that the methodology attempts to sink discussions on technical issues and refused to raise them to the level of principles, while the developing countries in this area trigged of clear manifestations matter, the developed countries stopped at the conventional discussions of check the base year for the selected indicators, and developed countries acceptance for the idea of new international economic order also means acceptance of the idea implied that economic mechanisms and financial force puppies in the world, do not work like what you do for traditional theory of international trade, and we mean by to equal rewards factors. (d . Ahmed, 1978, p. 68_69). 
1.4. create a new world economic order as an obstacle to North-South dialogue and its components and the impact of economic blocs on that system.

\subsection{1 create a new world economic order}

We mean by the new world economic order, "A group of rules and arrangements that have been developed in the afterma2 f World War II to set the rules of behavior in the economic relations between different countries." Especially if we understand that this concept implies that the global economic that formed after World War II was an order of economic situation in the world in a particular manner, and here it must be pointed out that the word system in a new world economic order means Order, any order conditions along the lines of a particular relationship involves certain particular behavior rules, and thus becomes a concept that the World Order organization consists of a set of relations between specific parties through certain mechanisms. And that different parts of the components of the system consists of the global economy: the international monetary system was set up his International Monetary Fund, the international financial system was set up a World Bank, the international trading system was set up to him GATT. (Abdel Hameed, 2003, p.: 16).

As for the establishment of new global economic order, where first attempts at laying the basis of the Bretton Woods Convention institutions, the United States proposal included 44 countries targeted new world economic order, the number of States Members in the year 1995, after nearly fifty years of its inception to 179 countries. ( Abdul Hameed, 2006, p.: 68). The objective of the Bretton Woods was to establish the background to the role of international trade and finance, and moreover, they have led to the emergence of multinational companies to provide stability to relations of trade and exchange, as well as opposition to any attempt or possibility of emergence to national economy threat, and prevent any attempt to re-emergence of a lethal national economy which was a reason to ignite World War II and in accordance with the views of decision makers and researchers. (241p:, Roe Goddard, 2005). Since this system boosted by the three main pillars, as stated at the begining (the international monetary system, international financial system, the international trading system, and sponsored by three international organizations belonging to the Organization of the United Nations.

\subsection{2 components of the new world order}

\section{First: the international monetary system}

This is a system that governs and sets rules of conduct in all matters relating to exchange rates and payments balance and the sources of deficit, financing and quality of corrective policies that allowed to a State Member, followed and applied for treatment of such a deficit when it occurs, and thus assumes that the achievement of global monetary stability in the new world economic order is ensured. The International Monetary Fund (IMF) is the keeper, which is based on the management of the international monetary system.

\section{Second: the international financial system}

It is a system which governs the rules of conduct in all matters relating to international moves or transfers of capital, whether in the form of foreign aid or foreign loans, and whether formal or business or in the form of foreign investment directly or indirectly. The World Bank WB in its destruction leading role in the management of the international financial system.

\section{Third: the international trading system}

It is the system which governs the rules of conduct in all matters relating to export and import of goods, and determine what may or may not be of protectionist measures or export subsidies, and even to work through this system of global trade liberalization to increase international exchange and establishing interdependence principle, and to maximize the return from trade to all parties of the international global economy, the World Trade Organization WTO take over management of the international trading system. (d. Hameed, 2003, p.: 38).

\section{5. economic blocs effect on the global economic system}

The tension of international relations output, in particular for the consequences of colonial and imperialism policies, of manifestations of underdevelopment large parts of the world while other parts enjoying the best cases of well-being and prosperity. This is apart from the advanced capitalist countries of monopolizing all forms of science and methods of technology and science development in all fields. Where this failure increased when Nordic countries established the economic blocs. (Alqose, 2002: p. 303).

One of the most important characteristics of the global economic system is an increased growing trend towards the formation of giant economic blocs, to be a range of entities diminishing the importance of the economy, which is working alone in one state when designing economic policies that deal with the outside world, but the economic territory is replaced in this area in a group for the largest possible gains from international trade. These economic 
blocs reflects, a high degree of intensity of interdependence and international division of labor, investment and trade, and that systems of economic integration and economic blocs in all its forms, including about $75 \%$ of the world and controls about $85 \%$ of world trade, from these blocs, the European economic bloc, the North America economic bloc's NAFTA, the Asian economic bloc, in addition to African economic bloc and Latin America. (D. Hameed, 2003, p.: 119). European bloc is one of the largest economic blocs in the world and most complete in terms of development and maturity stages, and this bloc became in the eyes of many researchers, the largest economic power and most powerful in the world, of whom Samuel Hantekton when he said "that if the European Community became a coherent political will then resources human and economic wealth, technology and potential military power and actual power to become highlighted in the twenty first century" (Joseph S., 1991, p.: 128). As this bloc to achieve an annual volume of foreign trade up, on average, to 1150 billion dollars, which accounts for more than a third of world trade and greater than the size that gets farm NAFTA. The economic bloc of North America, is differs from the European economic bloc, where it stands at the stage of establishing a free trade zone without be extended to the establishment of a customs union or common market, and includes both the United States, Canada and Mexico. President Bill Clinton tried many times to convince the Congress to enter the United States Free Trade Agreement, NAFTA, and ratified by Congress in 1993 after internal disputes because of economic disparity and social for States Members. (D. Ithawi, 2009, p.: 187). Where Clinton Dodge during his election campaign, said he would not agree to the Convention but only if the rights of workers added to, and a minimum environmental standards, said in San Diego "I will support expanded trade with Mexico and all these countries, only if they raised the level of wages and labor standards and Clean up the environment so that we can all board instead of sliding to the bottom "in November 4, 1992 was elected as president, and that was a major cause of his victory in elections. (Jeff Fu, 2009, p.: 19). The field of trade in NAFTA is one of the most important areas of the vast and profitable for States Member sin NAFTA. The Asian economic bloc, one can say that the Asian economic bloc still in formative stage, but there are sophisticated and constantly changing in this direction, especially in light of the increasing rates of economic growth in South East Asia states in particular and increased its contribution to international trade, either by Japan or by rising and rising Asian Tigers, or so-called industrialized new countries, and the desire of the Asian Tigers to protect themselves from a indirect protectionism wave resulted from the economic bloc of North America or European Economic Community bloc. (Dr. Abdel Hameed, 2003, p.: 133). The Association of South East Asia ASEAN consists of six countries are Thailand, Singapore, Malaysia and Brutay, Indonesia and the Philippines, the Association established at the outset as a kind of political alliance in 1967, in the face of communism in South East Asia, especially Vietnam, Cambodia, Laos and Burma. The conglomerates in Latin America, where it has several pictures of blocs, including the Common Market for Central America and the Commonwealth of ANDEAN Group and the Caribbean free trade. ANDEAN has shown some success and achievements of the possibility of finding a regional entrance to economic bloc, the most appropriate to the circumstances of developing countries. Also the case for the African economic blocs, there are a lot of economic blocs to AFRICA that serves as a regional approach to the economy of that region. There is also the so-called Group of Eight G8, which consists of the United States of America, Britain, Italy, France, Japan, Russia, Germany and Canada, so that the eight countries represent $14 \%$ of the current world population. However, representing two thirds of the global economy compared to gross national product.

1.6 Subsidies from North to South (United States relief program in its foreign policy) as a mean of control over the countries of South in the light of globalization.

South States are of more countries that receive subsidies and assistance from Nordic countries, led by the United States of America, which made the foreign relief program is one of its objectives to achieve security goals, because of many suffers by many south countries of the issue of economic, political and social backwardness, which led them to depend on foreign aid, particularly from the United States of America.

Although the emergence of programs of Official Development Assistance ODA as a tool to achieve foreign policy objectives is a relatively recent phenomenon no more than five decades, it is a short period if compared with emergence of nation-state and the beginning of the international relations era, but it soon proved its efficiency as an effective tool in the implementation of foreign policy, especially during the Cold War period, and achievement of objectives of foreign policy by the aid. The development of foreign aid which is the comprehensive term that includes not only ODA but also military assistance and humanitarian aid in 1942 through the Lend-Lease directed to support the military capability States are allies to the United States during World War II and later Marshall Plan to rebuild Europe after the war, the United States has continued for a long time enjoyed the only source of foreign aid. (Jad, International Politics Journal, No. 5, pp: 101). Perhaps the USAID program is one of important tasks that upon which U.S. foreign policy based on, so that the percentage of spending the U.S. aid in 1990 to 274 billion dollars to more than 100 developing countries, The foreign aid program is one from important programs in the implementation 
of U.S. foreign policy, it serves the American interests through provision of economic and military aid to support the stability of key countries in the strategy, also the U.S. economy benefits as well as from a program of food aid and importation program of goods but the continuation of the program as it is, where the priority is for security objectives and finally to support democracy through the promotion of political and social pluralism, finally, the Foreign Affairs Committee of the Congress proposed to focus on treatment the military cooperation from the military assistance program and not to focus only on achieving a political strategy objectives. So, the purpose of the U.S. economic and military aid is to maintain the security and strategic interests of the United States of America. (Jad, International Politics Journal, No. 5, R: 106). What is the so-called U.S. aid, food and agricultural and economic development of poor countries was not a field to do good or for sympathy and love with the peoples of these countries, but was also and as identified by U.S. law No. 480 of 1954 which organized to solve the stocks accumulation of products and cereals, especially wheat, so as this accumulation not harm the universal price of these vital commodities that is on the one hand, on the other hand they are used as important weapon to dominate the peoples and placement of the South poor states to implement the directions that serve foreign policy of the United States of America, and, when deemed necessary for its national security, law of the U.S. mutual security letter that it not allowed to grant economic or technical aid for any foreign country but only if these grants supports U.S. security. This was confirmed by Jack Hoover who one manufacturers key for and foreign food and agriculture policy for America clearly affirms: "We do not distribute food to other countries on the basis of the invasion, but on the basis of considerations dictated by U.S. foreign policy. (Nassif, 2004, p.: 239). This policy is for United States of America also evident through its control of the International Monetary Fund, this policy was quite clear at meeting of the International Monetary Fund in 1983, devoted to talk about the accumulated debt of developing countries, in light of serious financial problems and financial and economic crisis that hit the whole capitalism world and its impacts on developing countries and their economic and political development, so that the Department of the World Bank worried about the accumulation of huge debts of developing countries by $\$ 74$ billion in 1970, but raised at the end of 1982 to about 626 billion dollars and as a result of interest high rates, increased debt service to 131.3 one billion dollars in 1981, United States tried through its impact on International Monetary Fund to increase membership dues by $47 \%$ in terms of what these resources used in any proportion in promotion of the economy and the economic development of South countries, they sought to collapse the economic basis of the South developing countries. (Sarhan 0.1985 , pp: 60-61). development did not achieve in the last fifty years what was hoped for the most countries of the South, but the positions of some countries has declined to less than achieved in the sixties of the growth rates, poverty, ignorance and disease still to attribute the majority of the population in the south , matters arrived in some countries to collapse of the nation-state, thus increased the number of the population. (Abdullah, 1999, p.: 68). Nordic countries have used economic weapons in the face of countries of the South, to achieve economic gains, such as not equal economic profits to partners, and the desire of the partner which is effect reaches do to degree of political concession access, and the ability to implement the sanctions, so it is often the most powerful economically and politically than the targeted countries, and that the weakness of the south states economy because of its dependence on the north, and loans from international financial institutions. (Helen to his father, 1996, p.: 70). Thus the United States customized the bulk of its food aid to two types of countries, the countries of South-east Asia and the countries of the Near East, before the interest in Africa. So, the United States of America are of their roles through the economic impact in the course of the economic life of countries, which operations combine that the State done as aid for countries and investments carried out by private American companies own in those States, an increasing importance to influence the political decisions of the States. It could be argued that the emergence of the concept of lobbyists in the United States as a tool to analyze the relationships between institutions in the American political system, has demonstrated to a large extent its success in understand and study the subject of this phenomenon, from this view, the historian American Jwil Benin say "that understanding the mechanisms of the US-Israeli relations, and how the impact of these recent U.S. decision, requires using of tools and concepts of political economy." (Salimi, 1997, p.: 139-140).

\subsection{Globalization and the future of the dialogue between North and South}

It is obvious after we define globalization to us that globalization is a clear overlap of political, economic, social and cultural matters without esteem political borders of sovereign States, or belonging to a specific home or to a particular State, and without the need for government processes. On the economic level, globalization assumes that the processes of economic exchanges taking place on a global scale, away from the control of the nation-state. Or it is an economic activity beyond the limits of the nation-state, the economic administration and economic decision-making and the decisions of production, distribution and marketing are organized on a global level. (Al-Otaibi, Arab Journal of Political Science, 2009, No. 23, p.: 81). 
In fact, globalization has helped, according to the views of many researchers to widen the gap between the North and the South, citing the words of former U.S. President Bush when he said after the end of the second Gulf War, "The next century will witness the spread of American values and lifestyles and behavior the U.S." This speech was interpreted by many of researchers that there is no place for developing countries, and especially Arab, as the United States of America is controlled the tools of globalization, or rather, globalization means Americanization. We can identify the most important features of economic globalization with the beginning of the twenty-first century, including: the growing trend towards economic bloc to take advantage of developments from the tremendous development, and growing the role of transnational companies and the increasing its profits and expanding their markets and the growing influence in international trade and investment. The most important institutions or tools of globalization: the International Monetary Fund, World Bank, World Trade Organization.

The question that arises is whether those organizations or institutions affected by the achievement of raising the living and income standard and to achieve full employment and to achieve significant economic growth, and increase production and expand trade and other targets, why did not achieve in developing countries over the establishment of such organizations? Answer to that question: Some people believe that the reason is that developing countries themselves, because they do not adhere to policies proposed by these organizations to achieve those goals. Some would say that the reason is the North and the capitalist countries that have managed to control these organizations and guide them to achieve their interests, even if opposed to the interests of the South or developing countries, and Nordic countries the major creditor linking to approve the scheduling of the debt of developing countries, to bring a letter from International Monetary Fund proves subject to its policies and World Bank policies. This confirms that the aim of these policies is to make the country in which they were implemented, able to pay its external debts and facilitating transfer profits of foreign investments to outside, without working to achieve real economic development in this country, and that is from the hidden objectives which are headed by pillaging the resources of developing countries. The liberalization of markets is not from the interest of developing countries because of varying its situations and from different situation of developed countries or the Nordic countries, and because this liberalization leads to increased external deficit, not reduced, because justice requires taking into account the conditions of south States and not to open the door in developing countries before the flood of developed Western goods and services. Although there are who see that the phenomenon of globalization in all its exciting rhythms provide more opportunities and possibilities that could contribute to solve many of the chronic problems afflicting the Third World. However, there is a trend seen the opposite and emphasizes that globalization in its current position will contribute to further aggravation of crises and problems of many countries of the south world from one side and thus deepen the gap between North and South on the other hand except for some third world countries especially in the Asian continent, which was able to achieve great development leaps over the past years. (Almkhadmi, 2004, p.: 166). In South developing countries, things escalate rapidly and more sharply. The financial crisis revealed in the summer of 1997 on the fragility of financial systems in countries of the South-east Asia and some Latin American countries, for example, where more than 1,3 billion people earn his living by dollars in one day does not get benefit from globalization in the socialist countries of Europe only a handful of citizens. (Haddad, 2000: p. 562).

What about the use of new technologies and consumer goods? That a minority of people gets the products Sony and Nike, and phone lines are still not reached to many areas in the world. The number of participants in the telephone lines in Africa is no more than the participants in the city of Tokyo or on the island of Manhattan in New York. (Haddad, 2000: p. 562). On the other hand, we note that the countries of the South did not seek to follow the policies poverty to decreasing, such as increase and develop the industrial production, reducing the birth rate, developing of agricultural sector, creation of productive sectors contributing in the composition of national income and the national capital. (Fahimi, 1997: p. 139). In return for these problems that the South world states suffering from, the Nordic states have all means of domination and control to the South world and of the magnitude of capital and sophisticated and complex manufacturing modern technology and capabilities of high and advanced productivity, multinational companies and a variety of activities, an abundance of food and means of advanced communications and wide range network of financial and monetary institutions. (Fahimi, 1997: p. 139). Therefore, the countries of Nordic world adopt a strategy of marginalization towards world of South through the activation of the globalization institutions and deepening its political and economic dependence for advanced industrial countries. This means that globalization is driven by the wheel of the future of North-South dialogue towards crisis and complicated, because the North and especially the United States of America owns the tools of globalization and control of the globalization institutions, including the World Trade Organization and the World Bank and others.

\section{Conclusions}

The study reached the following conclusions: 
1. As Globalization intervenes in the affairs of a country's economic and political structure through institutions which are controlled by the United States, and therefore, these institutions are known to act on behalf of the Nordic countries, especially the United States of America.

2. Globalization is, from the economic side, opening markets and making them free of customs restrictions, and this is not in the interest of countries of the South, because of the difference between their economic, political and social situation and the Nordic countries, and thus this constitutes an essential point impeding North-South dialogue at the present time and may hold on in the future.

3. Globalization brings about economic and political benefits to the Nordic countries at the expense of the South states.

4. The United States of America, described as a Nordic state dominating the international system, is able to achieve a large part of its interests through its aids to countries of the South states in the context of globalization, and through the globalization institutions itself as a state, which controls these institutions.

5. The Nordic countries at the present time are heading toward the same path in the future to impose their hegemony and control over the countries of the South by several means, all the more, trying to worsen the situation of the countries of the South and their inability to meet challenges and policies of penetration by foreign powers.

6. The sovereignty of an unequal relations pattern between the industrialized North and the countries of the South will be the world's status quo in the future in the light of globalization and its institutions.

7. The countries of the South represent a heterogeneous group that lacks the ability to impose its will on the international level, as it lacks the ability to make decisions of unity. It is unable to develop firm stances in facing international political problems that could threaten its security and stability at present and in the future.

\section{References}

Abdel Hameed, Dr. Abdel Muttalib. (2003). New world economic order (and its future prospects after the events of September $\left.11^{\text {th }}\right)$, Neil Arab group, first edition, Cairo.

Abdel Hameed, Dr. Abdel Muttalib. (2006). Economic globalization (organizations - companies - implications), Dar Al-jamieh.

Abdullah, Abdalkhaleq. (1999). Roots and branches of globalization and how to deal with them, Alam Al Fikr magazine, issued by the National Council for Culture, Arts and Letters, Volume Twenty-eighth second issue, the State of Kuwait.

Abdullah, Ismail Sabri. (1999). Arabs and the Challenges of the Global System, Center for Arab Unity Studies, first edition, Beirut.

Ahmed, D. Kader Sayed. (1977). North-South dialogue, its foundation and its consequences, Arab Development Institute, First Edition, Beirut.

Ahmed, D. Kader Sayyed (1978). The new global economic system and the North-South dialogue, Arab Development Institute, First Edition, Beirut.

Akariminyuk, F. (1985). America and the national liberation movements, Dar Al-damishq, first edition, translation by: Shafik Mahmoud Shaaban.

Al-Jihad publications. (1988). (cultural Islamic common intellectual), America's strategy of hegemony and terrorism, a scientific study in the foreign policy of the United States of America, preparation by: the Research and Studies, Summer in June 1988.

Al-masri, D. Shafiq. (1992). The new world order, Dar Ilm, the first edition, Beirut.

Almkhadmi, Abdulkadir Rizieq. (2004). Dialogue between North and South (towards equitable economic relations), Dar Al Fajr for Printing and Publishing Company, Cairo.

Alqoze, Muhammad. (2002). International relations in modern and contemporary history, p 1, Dar Al-Nahda Al arabia, Beirut - Lebanon.

Azzam, Suhail. (2003). Globalization, Irbid, Jordan.

Bilis and Smith. (2004). Globalization of world politics, p 1, translation and publication of Gulf Research Center.

C.Roe Goddard. (2005). International Political Economy, Viva Books Private Limited, first Indian edition, ISBN 81-7649-865-3. 
Fahimi, Abdel Kader. (1997). The international political system (study in modern theoretical assets and properties), p 1, Dar Wael for printing and publishing.

Gad, Mohamed, foreign U.S aid and. security goals, international politics, file, Issue 5.

Haddad, Raymon.. (2000). International relations, p 1, Al-haqeqa House, Beirut.

Hadiyyeh, D. Abdulla. (1986). North-South dialogue and the crisis of international division of labor, multinational corporations, Dar Al-shabab for publication, first edition, Cyprus.

Harib, D. Said. (2000). Culture and Globalization, University Book House, p1, Al Ain.

Helen labieh, Mary. (1996). The economic struggle in international relations, Dar Oweidat publications, first edition, translated by: Hussein Haidar.

Ithawi, D. Yassin. (2009). American policy between the Constitution and the political forces, Dar Osama for publication and distribution, the first edition, Amman, Jordan.

Jeff Fu. (2009). World class war, Dar Al-Farabi, Mohammed bin Rashid Al Maktoum institution, first edition, translated by: Asaad Al-Hussein.

Joseph S., Nye G. R. (1991). Inevitability of leadership (the changing nature of American power), Jordanian books Centre, translated by: Abdul Qader Osman.

Mahmoud, Yasser. (2006). Impact of globalization on poverty in developing countries with reference to Egypt, Afaq Ektisadia Journal, Volume 27, issue 107, quarterly specialized magazine issued by Research and Documentation Centre, United Arab Emirates.

Mamsr, Muhammad. (2002). Impact of globalization on contemporary good Arab (Center of Excellence for Non-governmental organizations), Research and Studies, Amman - Jordan.

Massad, Mohi. (2004). Role of the state in a globalizing world, p1, Alexandria book Center.

Nassif, Eryan, intellectual issues, magazine. (2004). A challenge to American hegemony, the way to alternative democratic globalization, issued by the intellectual issues of publication and distribution, ISBN: $18472 \backslash 2004$, Cairo.

Otaibi, Abdullah bin Jabr. (2009). Globalization and national sovereignty of the state, Arab Journal of Political Science, published by the Arab Association of Political Science in cooperation with the Centre for Arab Unity Studies, No. 23.

Salimi, munsif. (1997). American political resolution, the Arab-European Studies Center, the first edition.

Sarhan, Mohamed (1985). The danger of U.S. policy and deterioration of the global economy, Dar Al-Galil for printing and publishing, first edition, Damascus.

Tai, Ghazi. (2004). World Trade Organization and its economic effects in developing countries, Afaq Ektisadia Journal, Volume 25, issue 97, quarterly specialized magazine issued by Research and Documentation Centre, United Arab Emirates. 